SAR (Soedirman Accounting Review): Journal of Accounting and Business

Journal Homepage: $\underline{\text { http://jos.unsoed.ac.id/index.php/sar/ }}$

\title{
DETECTION ANALYSIS ON FRAUDULENT FINANCIAL REPORTING USING FRAUD SCORE MODEL
}

\author{
Puput Ade Irawan $^{1}$, Dewi Susilowati ${ }^{2}$, Novita Puspasari ${ }^{3}$ \\ Accounting, Faculty of Economics and Business, Universitas Jenderal Soedirman. \\ E-mail corresponding author: padeirawan@gmail.com
}

\begin{abstract}
This study aims to examine the elements of fraud in the fraud diamond theory. Fraud is proxied by seven variables consisting of three pressure elements namely financial target, financial stability, external pressure, two variables of opportunity element, namely effective monitoring and nature of industry, one variable from the rationalization element, namely change in auditor, one variable from capability element namely change in directors, which is hypothesized to affect financial statements fraud. This study uses earnings management to see the potential for fraudulent financial statements. Earning management is measured using the F-Score indicator. The research sample was selected using a purposive sampling method from 30 manufacturing companies and a research period of 5 years to obtain the number of sample units of 155 data which is listed on the Indonesia Stock Exchange (IDX) for the period of 2013 to 2017. The hypothesis testing used a multiple regression analysis model using SPSS 23. The results of the study indicate that financial targets and changes in auditor financial stability have a significant positive effect on fraudulent financial statements. While external pressure, effective monitoring, nature of industry, financial stability, change of directors, have no effect on financial statements fraud.
\end{abstract}

Keyword: Fraud Score Model, earning management, financial statement fraud, fraud diamond

\section{INTRODUCTION}

Every company has the main goal, which is to get profit in each period. Sustainability to achieve profit according to the target in each period will attract investors to invest in the company. The company's financial statement is a communication tool that has the function to disclose financial information for a certain period to the users, both from internal and external parties. Financial information is used by users of financial statements for various things, for example for manager's decision making, management performance assessment, investment feasibility, debt feasibility assessment, tax calculation, and public accountability.

The information contained in financial statements must reflect the entire accounting process within the company and meet existing information criteria. Financial report criteria are information that is relevant, complete, reliable, timely, understandable, verified and accessible. In the organizational structure, management is playing an important role to meet these criteria. If these criteria have not been met, financial report users cannot use financial information fully. (IAI, 2015).

In fact, there are still companies that do not present financial reports that meet the quality of information. One of the reasons is fraud committed by management to gain personal and group benefits. An employee who intentionally causes misstatement or negligence of material information in the organization's financial statements. One reason fraud committed by management to gain personal benefits. 
Association of Certified Fraud Examiners or ACFE (2018), stated that, there are three schemes of fraudulent actions carried out by management and employees within the company, fraudulent work in which employees, managers, officials, or owners of organizations commit fraud to the detriment. The scheme was first introduced in 1996 and continues to be refined to date. The ACFE represents it in a chart fraud called "Fraud Tree". The tree has 3 branches, namely: (1) Corruption, is the act of someone who misappropriation trust in a problem or organization to make a profit.(2) Asset Misappropriation, is a form of fraud with loss of assets of an entity, misuse of assets is usually carried out by internal company employees. (3) Financial statements fraud, is intentional or negligent in reporting financial statements presented not in accordance with accounting principles.

Financial statements fraud has the greatest impact on losses for the company (Imam Ghozali, 2016). This big loss occurs because financial report fraud perpetrators are dominated by top managers or people who have more authority in the company, so they are easy to manipulate or cheat. This fraud is called "White Collar-Crime". Cases of conflict of interest are one of the most difficult to investigate on white collar violations, because it generally occurs at the top of an organization and involve several characteristics that present a unique challenge for an examiner.

One method of fraud financial reporting is that earnings management take place when managers use valuations in financial reporting and in preparing transactions to change financial statements that mislead stakeholders. Earnings management can influence stakeholder perceptions depending on the financial report figures reported (Healy and Wahlen, 1999). Financial report scandals that take place in Enron and WorldCom companies change the view of earnings management into a negative (opportunistic) perspective, even managers tend to have their own interests, not for the interests of stakeholders.

Misstatements and disclosure of intentional financial statements with the intention of deceiving the users of the report usually carried out by the management. The occurrence of fraud in a deliberate action that cannot be detected by an audit can have a detrimental and defective effect on the financial reporting process. In 2015, Toshiba was investigating an internal accounting scandal and had to revise the calculation of profits in the last 3 years. After being thoroughly investigated, it is known that Toshiba has difficulty achieving business profit targets since 2008 where in the middle of the global crisis.

The crisis also hit Toshiba's business until finally Toshiba made a lie through accounting fraud worth 1.22 billion USD. With unfavourable financial conditions, management takes actions with various efforts to produce profits that are not in accordance with reality. On July 21, 2015, CEO Hisao Tanaka announced his resignation regarding the financial report scandal which he described as the most damaging event of the Toshiba brand throughout the 140-year history of Toshiba's founding and followed by eight leaders who resigned, including the two previous CEOs. The name Toshiba was then removed from the stock index and experienced a significant decline in sales.

At the end of 2015, Toshiba had lost 8 billion USD. Company management sets unrealistic profit targets so that when the target is not reached, division leaders are forced to lie by manipulating financial report data. Toshiba has a corporate culture that demands compliance with superiors, and this is an important factor that results in the practice of financial report manipulation. In addition, the results of the investigation also showed internal problems so that Toshiba failed to prevent signs that were detrimental to the company. Although Toshiba management leaders have been working hard to restore the condition of the company, but until the beginning of 2017, Toshiba is still in the process of rising from the adverse effects of scandals in 2015 (integrity-indonesia.com, 2017)

Earnings management is carried out through accounting policies or by controlling accrual transactions. Accrual transactions are transactions that do not affect cash inflows or cash outflows. Accrual transactions consist of discretionary and non-discretionary transactions. Financial statements generally aim to provide information about the company's financial position, performance and cash flow to parties interested in the company, financial statement makers, therefore, must provide accurate, relevant information free from misstatement or fraud. To gain the trust of financial report users, especially investors, shareholders and creditors, the company will make financial reports accurate and relevant and free from misstatement material. Unfortunately, such conditions cause fraud in financial reporting. 
Association of Certified Fraud Examiners (2016), reported that in the last 5 years the level of fraud has continued to increase. In 2012 there were 7.6 percent fraudulent financial statements of total fraud, then increased in 2014 to 9.0 percent, and the latter increased to 9.6 percent in 2016. Fraud of these financial statements has the biggest loss, that is equal to $\$ 975,000$. Far different from the impact of losses caused by asset misuse and corruption, which amounted to $\$ 250,000$ and $\$ 200,000$. In addition, top managers and owners were the main perpetrators of fraud which resulted in the biggest loss, amounting to $\$ 703,000$. While the impact of losses by low-level managers and employees is $\$ 173,000$ and $\$ 65,000$.

Publications carried out by the Association of Certified Fraud Examiners (2018) of the three main categories of fraud, first, the most common asset abuse so far, is 89 percent of cases. However, they also caused an average loss of USD 114,000. Both schemes of corruption are the most common and job fraud totalling 38 percent of publications carried out by AFCE involves some form of corrupt action. The scheme resulted in an average loss for the victim organization of USD 250,000. The third is the most common fraud is financial statement fraud, there are 10 percent of cases and cause an average loss of USD 800,000 .

In previous studies, author used earnings management as the dependent variable to determine the potential for fraud in financial statements. Study related to the theory of fraud triangle and fraud diamond is a similar study because the two studies have almost the same variables, except that in the fraud diamond theory there is an additional factor, namely the ability indicator. There are many studies that have tried to prove the truth of both theories. However, there are still differences in results between one study and another. Therefore, author conducted a repeat research to prove the validity of the two theories, especially the fraud diamond theory because this theory was considered more complete and include all variables in the fraud triangle theory.

Statements on Auditing Standard No. 99, said that there are four pressure factors that can be proxied, those are by financial stability, external pressure, personal financial need, and financial targets. These four factors can lead to fraudulent financial statements. SAS no. 99 classifies into three categories found in Opportunity factors and can be proxied by the nature of industry, ineffective monitoring, and organizational structure. While the Rationalization and Capability variables are the most difficult variable parts of fraud diamond.

In previous studies, author used earnings management as a proxy for the dependent variable Most author use discretionary accruals as a measure of earnings management. In this study, earnings management was measured using a fraud score model developed by (Dechow et al., 2011; Eko Suyono, 2017). This tool is a common fraud risk assessment that produces output in the form of a model fraud score, an indication of the possibility of fraud in financial reporting (Dechow et al., 2011). Measurements often known as F-Score are considered effective and are suggested as first pass screening by accountants in detecting material misstatements in financial statements (Sukrisnadi 2010; Aghghaleh et al.,2016). While the independent variable used in this study is the pressure variable which is proxied by financial stability, external pressure, financial target; opportunity variables that are proxied by the nature of industry, effective monitoring; the rationalization variable that is proxied by changes in auditors; and capability variables that are proxied by changes in directors. Of the four factors, an increase in fraud occurred in the company's financial statements.

\section{LITERATURE REVIEW AND HYPOTHESES DEVELOPMENT}

\section{Agency Theory}

Agency theory is used to explain agency relationships that occur within a company. In this theory what is meant by agents is played as company management, while principals are owners. Both of them establish a correlation in a cooperation agreement and have hope for such cooperation to improve the welfare of each of the principals and agents. Agents have more information than principals. One of the fraudulent actions that are often carried out by agents is manipulating information presented in financial statements. (Jensen and Meckling, 1976; Ross, 1973). 
Asymmetric information raises costs called agency cost. This cost arises because the principal tries to reduce the asymmetric information to the lowest level in order to guarantee that the decisions taken by management are in accordance with what they want (Nurbaiti and Hanafi, 2017). There are 3 types of agency costs, which cause asymmetric information, namely (1) costs incurred due to the agent's decision that is not in accordance with the principal's interests, (2) costs incurred to maintain the alignment of interests between the principal and the agent in accordance with the contract, and (3) costs incurred to monitor agent actions (Jensen and Meckling 1976).

\section{Fraud Diamond Theory}

This theory was put forward by Wolfe and Hermanson (2004) who added the ability factor to complement the theory revealed by Cressey (1953) by introducing fraud triangles that could be used to detect potential fraud. There are three elements of the fraud triangle theory which are the causes of fraud, namely: Pressure, Opportunity, and Rationalization. So that the new theory explains that there are 4 factors that influence a person to commit fraud, namely capability. These four factors are known as fraud diamond. The characteristics described by Wolfe and Hermanson (2004) are related to the element of ability in fraudulent actions, namely: Position and function, intelligence and creativity, selfconfidence and ego, coercion and skill, effective lying, immune to stress.

\section{Definition of fraud}

The Association of Certified Fraud Examiners (ACFE) defines fraud as a fraudulent act made by a person or entity who knows that this error can result in losses to individuals or entities. Fraud is an act and action which is done intentionally, consciously, knowingly and desires to abuse everything that is held together, both in the form of company and state resources for the personal enjoyment and then presents incorrect information to cover up the abuse (Ernst \& Young, 2017). From several definitions above, it can be concluded that fraud is an act and an unlawful act carried out by someone from inside or outside the organization that is done intentionally with the aim of gaining personal and group benefits but on the other hand also harms others. (Albrecht et al, 2012)

\section{Typology of Fraud}

The Association of Certified Fraud Examiners (2018) describes a fraud scheme in the work place called the fraud tree and divides fraud into 3 typologies of action, namely: (1) Corruption scheme is a fraud scheme that is difficult to detect because in practice this fraud involves many parties that cover each other. (2) Asset misappropriation is a fraud that is easiest to detect because it has a tangible nature or can be calculated. This fraud often occurs within the company, when an employee asset misappropriation company improperly and for personal gain. (3) Fraudulent Financial Statement is an action taken by top-level managers in a company to cover up the actual financial condition by conducting financial engineering in the presentation of financial statements.

\section{Financial Statement Fraud}

The Association of Certified Fraud Examiners (2018), describes two fraudulent actions taken to manipulate financial statements. First, the perpetrator manipulates financial statements by presenting lower than actual income. The lower presentation has an impact on the company's obligation to pay taxes to the government or other obligations. The second mode, by presenting higher than actual income. This mode is done so that the company's financial performance looks good so that the users of financial statements, especially investors and creditors, are increasingly convinced of the company's prospects. 


\section{Accrual Quality}

The Fraud Score Model is the sum of two variables namely accrual quality and financial performance of Skousen and Twedt (2009). The Fraud Score Model in this study is used as a calculation to measure the level of fraud risk in financial statements which is calculated by summing financial performance with accrual quality (Aghghaleh et al, 2016). Earnings management is used as one of the independent variables in this study because it is considered as one of the factors in its occurrence fraudulent financial statement. This can happen because if in a condition where the management failed in achieving the profit target determined, management is motivated to show good performance in generating maximum value or profit for the company (Halim et al., 2005).

The accrual basis in financial statements provides an opportunity to the manager to modify financial statements to generate profits desired (Halim et al., 2005). The amount of accrual reflected in profit calculation consists of discretionary accrual and non-discretionary accrual. Non-discretionary accruals are accrual components that occur along with changes in company activities, while discretionary accrual is an accrual component derived from earning management done by the manager.

\section{Earnings Management}

Earnings management is an intervention for management of financial reporting processes for personal gain. By using the agency theory perspective, fraudulent financial statements by management through earnings management schemes occur when there is a conflict of interest between management and shareholders. This conflict of interest raises a difference in information held by management and shareholders. When supervision by shareholders through the board of commissioners is weak, the difference in information will increase so that the higher the agency cost is needed (Habib., 2013).

Earnings management is motivated by management's desire to get a good rating before shareholders (Healy and Wahlen., 1999) in (Kurniawansyah, 2018). Shareholders will certainly believe in the performance that has been shown by management because its interests have been fulfilled by getting a high return on what has been invested. Management will also fulfil its interests by getting an application in the form of additional incentives for performance from shareholders, but in reality, the results of the performance are only manipulations.

\section{Research Hypothesis}

Financial stability is part of the pressure variable in fraud diamond. Financial stability is a picture of the company's financial condition seen from financial stability. SAS No. 99 (AICPA 2002), When the value of asset growth in a company is below the industry average, it will encourage management to manipulate asset values so that it will improve the company's prospects in the public eye. Loebbecke, Eining, and Willingham (1989) in (Skousen et al., 2009).

Kennedy Samuel Sihombing and Shiddiq Nur Rahardjo (2014), Prasmaulida (2016) and Iqbal and Murtanto (2016) show that financial stability has a significant positive effect on the potential for fraudulent financial statements using the total asset change ratio (ACHANGE) as a measure of financial stability. These results support the research conducted by Skousen, et al (2009), with the higher ratio of changes in the total assets of a company, which means that the higher the growth of a company's assets, the higher the potential for fraudulent financial statements. Based on these descriptions, the hypotheses used in this study are as follows:

\section{Ha1 : Financial stability has a positive effect on the potential for financial statement fraud.}

External pressure is part of the pressure variable in fraud diamond. External pressure is a pressure condition faced by management because it must meet the requirements of an outside 
company. One source of external pressure when in order to increase funding sources to improve company performance, but companies find it difficult to meet credit requirements and there is a concern that when the debt is due, the company is unable to return it Skousen, et al.(2009), (Iqbal and Murtanto., 2016) and (Sunardi and Nuryatno., 2017).

Research conducted by (Indarto and Ghozali, 2016; Nanda Santoso, 2017) measuring external pressure which is proxied by leverage ratio has a significant positive effect on the potential of fraudulent financial reporting. The higher the debt made by the company, the higher the potential for fraudulent financial statements carried out by management. Based on these descriptions, the hypotheses used in this study are as follows:

\section{$\mathrm{Ha2}$ : External pressure has a positive effect on potential for financial statement fraud.}

Financial target is part of the pressure variable in fraud diamond. Financial targets are financial targets in one period that must be met, managers are asked to show their best performance in achieving the planned targets. This becomes a pressure for managers in carrying out their performance which is required to always maintain the financial targets set by directors and management. From this pressure allows a manager to manipulate financial statements so that the company's finances are in accordance with predetermined targets (Skousen, et al 2009).

Research conducted by Indarto and Ghozali.,(2016); Nugraheni and Triatmoko.,(2017) and Nanda Santoso., (2017), show that ROA has a significant positive effect on the potential for fraudulent financial statements. The higher the ROA target in a company, the higher the potential for fraudulent financial statements made through earnings management. If the target of ROA is high, management will try to achieve these targets. When a company's ROA shows a low value, it allows management to manipulate financial statements by raising existing profits. Based on these descriptions, the hypotheses used in this study are as follows:

\section{Ha3 : Financial targets have a positive effect on the potential for financial statement fraud.}

Nature of industry is part of the opportunity variable in fraud diamond. Nature of industry is the ideal state of a company in an industry. The economic environment and industrial regulations in a place where the company operates are one of the gaps for companies to practice fraudulent financial statements (Santoso,2017). Inventories are included in current assets that are prone to be stolen and rigged because they are easy to cash. In addition, companies usually have a large inventory value so that the inventory account has a significant influence on the balance sheet or profit and loss calculation.

Research conducted by Summers and Sweeney, (1998). measures the nature of the industry by using the ratio of total inventory change and the ratio of total changes in accounts receivable. The result of these two measuring instruments can prove that the nature of the industry has a significant positive effect on the potential for fraudulent financial statements. The higher the ratio value of a company's total inventory change, the higher the potential for fraudulent financial statements. In line with the research of Sihombing and Rahardjo (2014) stating the nature of the industry has a positive effect on fraudulent financial statements. Based on these descriptions, the hypotheses used in this study are as follows:

\section{Ha4 : Nature of industry has a positive effect on the potential for financial statement fraud.}

Effect monitoring is part of the opportunity variable in fraud diamond. The board of commissioners is an accomplice of shareholders to directly oversee management in making business decisions, ensuring accountability and ensuring the company's strategy is implemented. There are two types of a board of commissioners, the first is the board of commissioners, second is an independent board of commissioners. The aim is to maintain the neutrality of the board of commissioners in overseeing management performance. With the existence of an independent board of commissioners 
on the board of commissioners will increase the effectiveness of the board in overseeing management performance (Sihombing and Rahardjo, 2014).

This is also supported by research conducted by Dechow et al (2011) which uses the ratio of an independent board of commissioners as an indicator of effective monitoring. The results prove that the potential for fraudulent financial statements is more common in companies that have fewer independent board members. Thus, it can be concluded that the higher the ratio of an independent board of commissioners in a company, which means that the more effective supervision carried out in the company, the lower the potential for fraudulent financial statements to occur. Based on these descriptions, the hypotheses used in this study are as follows:

\section{Ha5: Effective monitoring has a negative effect on the potential for financial statement fraud}

Change in directors is part of the capability variable in fraud diamond. In the study of Wolfe and Hermanson (2004) argued that fraud would not occur if no person had the ability to carry out the fraud in detail. Therefore, the position of CEOs, directors, and other heads of divisions is considered the ablest to prevent or vice versa, namely utilizing these capabilities to commit fraud. Substitution of directors is the transfer of authority from the old directors to the new directors with the aim of improving the performance of the previous directors.

Using the change of directors as a measure of the capability to determine the potential for fraudulent financial statements (Manurung and Hardika., 2015). The study succeeded in proving that the change of directors had a significant positive effect on the potential for fraudulent financial statements. Thus, it can be concluded that if more frequent changes in directors within the company, the potential for fraudulent financial statements will also be higher. Based on these descriptions, the hypotheses used in this study are as follows:

\section{Ha6 : Change of directors has a positive effect on the potential for financial statement fraud.}

Change in auditor is part of the rationalization variable in fraud diamond. Rationalization is often associated with the attitude and character of someone who justifies an unethical action according to the wider community. Rationalization is an attitude that allows or considers it reasonable if someone commits fraud. To reduce the possibility of detecting fraud committed by companies, companies usually change auditors more often to cover up (Skousen et al 2009). With the replacement of new external auditors, it still does not understand the overall condition of the company. So that there is undetectable fraud committed by management by the auditor.

Research conducted by (Loebbecke, et al., 1989) in (Skousen et al., 2009) shows the risk of higher audit failure at the beginning of the auditor tenure compared to the following years. So that it can be concluded that the more often companies make changes to external auditors, the higher the potential for fraudulent financial statements carried out by management. Based on these descriptions, the hypotheses used in this study are as follows:

\section{Ha7 : Change in Auditor has a positive effect on the potential for financial statement fraud.}

\section{RESEARCH METHODS}

\section{Population and Sample}

This study uses a population report on manufacturing companies listed on Indonesia Stock Exchange in 2015-2017. The reason for using manufacturing companies' financial statements is because the business processes and accounting processes in manufacturing companies are longer than other types of companies, so the potential for fraud tends to be greater. Starting from the purchase of raw 
materials, processing the raw material into finished goods or called the production process, until the goods are in the hands of consumers.

In choosing a sample, the author uses a purposive sampling technique. According to Widarjono (2015), purposive sampling is a sampling method with the consideration that the sample was chosen can represent the population studied, in other words, the sample is chosen based on predetermined criteria. The criteria used in this sampling are as follows: (1) Manufacturing companies listed on the Indonesia Stock Exchange for the period 2015-2017. (2) Publish annual financial reports on the company's website or the website of the Indonesia Stock Exchange during the period 2015-2017. (3) Disclose data relating to research variables and are available in full in publications during the period 2015-2017. (4) Not delisted from the Indonesia Stock Exchange during the period 2015-2017. (5) Not shifting sectors during the 2015-2017 observation year.

\section{Operational Definition and Variable Data Measurement}

This study aims to analyze the relationship between independent variables which are fraud diamond components with the dependent variable, namely the potential for fraudulent financial statements. This study uses numbers as indicators of research to answer research problems so that this study uses quantitative methods as an approach to analyze research problems. This study analyzed 8 variables consisting of 1 dependent variable and 7 independent variables. The definition and operationalization of each variable will be explained in detail as follows:

\section{Dependent Variables}

The dependent variable used in this study is the potential for fraudulent financial statements. This study detected the potential for fraudulent of financial statements by using fraud score models as determined by Dechow et al (2011). The F-Score model is the sum of two variables, namely accrual quality and financial performance (Skousen and Twedt 2009), can be formulated with the following equation:

\section{$\mathrm{F}-$ Score $=$ Accrual Quality + Financial Performance}

Variable components in the Fraud Score include two things that can be seen in financial statements, namely accrual quality, and financial performance. Accrual quality is calculated by accrual RSST. RSST stands for the names of researchers who introduced this formula, namely Richardson, Sloan, Soliman, and Tuna (Richardson et al 2005). This formula defines all non-cash and nonequity changes in a company's balance sheet as accruals and distinguishes the characteristics of working capital (WC), noncurrent operating (NCO), and financial accrual (FIN) and asset and liability types. The form of the formula is as follows:

$\begin{array}{ll}\text { RSST } & \frac{(\Delta \mathrm{WC}+\Delta \mathrm{NC}+\Delta \mathrm{FIN})}{\text { Average Total Asset }} \\ \text { Information: } & \\ \text { WC (Working Capital) } & \text { (Current Assets - Current Liability) } \\ \text { NCO (Non Current }= & \text { (Total Assets }- \text { Current Assets }- \\ \text { Operating Accrual) } & \text { Investment and Advances })-(\text { Total Liabilities - } \\ & \text { Current Liabilities }- \text { Long Term Debt) } \\ \text { FIN(Financial Accrual) }= & \text { (Total Investment }- \text { Total Liabilities) } \\ \text { AVT (Average Total }= & \text { (Beginning Total Assets }+ \text { End Total Assets) } / 2 \\ \text { Assets) } & \end{array}$

Financial performance of a financial report is considered capable of predicting the potential for fraudulent financial statements (Skousen and Twedt 2009). Financial performance can be seen through 
changes in accounts receivable, changes in inventory accounts, changes in cash sales accounts, and changes to before tax and interest earnings which can be formulated through the following equation:

Financial Performance

Change in receivable

Change in inventories

Change in chas sales

Change in earnings
$=$ Change in receivable + change in inventories + change in cash sales + change in earnings Information:

$$
\begin{aligned}
& =\frac{\Delta \text { Receivable }}{\text { Average Total Asset }} \\
& =\frac{\Delta \text { Inventories }}{\text { Average Total Asset }} \\
& =\frac{\Delta \text { Sale }}{\text { Sale }(\mathrm{t})}-\frac{\Delta \text { Receivable }}{\text { Receivable }(\mathrm{t})} \\
& =\frac{\text { Earning }(\mathrm{t})}{\text { Average Total Asset }(\mathrm{t})}-\frac{\text { Earning }(\mathrm{t}-1)}{\text { Average Total Asset }(\mathrm{t}-1)}
\end{aligned}
$$

\section{Independent Variables}

\section{Financial Stability}

The greater the ratio of changes in the total assets of a company, the potential cheating financial statements at a company is also getting higher. The research conducted ( Skousen et al 2008) uses a change ratio of total assets as a measure of financial stability. The ratio of changes in total assets (ACHANGE) can be calculated by the following formula:

$$
\text { ACHANGE } \quad=\frac{(\text { Total Asset }(\mathbf{t}) \mathbf{s}-\text { Total Asset }(\mathbf{t}-\mathbf{1})}{\operatorname{Total} \text { Asset }(\mathbf{t}-\mathbf{1})}
$$

\section{External Pressure}

External pressure is a perceived excessive pressure by management to meet the requirements or expectations of third parties. One source of external pressure is the ability of the company to fulfil debt requirements and return debt (Skousen et al 2008). An external pressure in this study is measured by the leverage ratio (LEV). Ratio leverage is calculated by the formula of debt to assets ratio, namely:

$$
\text { Debt to Asset Ratio }=\frac{\text { Total Debt }}{\text { Total Asset }}
$$

\section{Financial Target}

In carrying out their duties, the company manager is asked to show their best performance in achieving the planned targets. One measure of management performance is effectiveness and efficiency company in generating profits derived from utilization assets owned by the company. Return on assets (ROA) is a ratio profitability used to measure company performance (Skousen et al 2008). ROA can be calculated by the following formula:

$$
\mathrm{ROA}=\frac{\text { Earning After Interest Tax }}{\text { Total Asset }}
$$

\section{Nature of Industry}

Nature of industry is an ideal state of a company within the industry. The economic environment and industry regulations require companies to can make subjective judgments in estimating no collect receivables and the amount of inventory that has been obsolete (Summers and Sweeney 1998). Inventories include accounts liquid so it is prone to be stolen because it is easy to cash. Other than that, usually companies have a large amount of inventory, that is can be used by management to manipulate financial statements because the inventory account has a significant influence on the balance sheet and profit calculation. Therefore, research this uses the ratio of changes in total inventory as an indicator of the nature of the industry which can be calculated using the following formula: 


$$
\text { Inventory }=\frac{\text { Inventory }(t)}{\text { Sale }(t)}-\frac{\text { Inventory }(t-1)}{\text { Sale }(t-1)}
$$

\section{Effective monitoring}

When the monitoring system or monitoring runs effectively, this will have an impact on the decline in the potential of earnings management carried out agent or management in a company (Andayani,2010). Board of Commissioners independent is needed to improve the effectiveness of supervision against all management practices. Independent board of commissioners is Board of Commissioners members who fulfil the unaffiliated requirements are good with shareholders, directors, or other commissioners, not working concurrently with affiliated companies, and understand the laws and regulations in a capital market sector (Effendi 2008) in (Iqbal and Murtanto 2016). Because of this study measures effective monitoring with the board of commissioner ratio independent (BDOUT). The ratio of independent commissioners (BDOUT) can be calculated by the following formula:

$$
\text { BDOUT }=\frac{\text { Total Independent Boards }}{\text { Total Boards }}
$$

\section{Change in directors}

Change of directors will be able to cause an impact stress period on the opening of opportunities for fraud (Wolfe and Hermanson 2004). This study measures the proxy capability with the change of director company (DCHANGE). The measurement uses a dummy variable. If there is a change in company directors during the 2015-2017 period, it is given code 1, conversely if there is no change of company directors during the 2015-2017 period was coded 0 .

\section{Change in Auditor}

Rationalization is justification for fraudulent actions do. Rationalization tends to increase when it occurs a change of external auditor. Change in auditors in a company can be considered as an effort to eliminate traces of cheating discovered by the previous auditor. Some studies indicate that audit failure incidents increase when an auditor changes in a company (Skousen et al, 2008). The measurement uses a dummy variable. If there is a change of public accounting office during the 2015-2017 period, coding by 1 , conversely if there is no change in public accounting firms during the 2015 -2017 period were coded by 0 .

\section{Data Analysis Methods}

\section{Hypothesis Test}

Hypothesis testing is done to get valid data analysis results and support the hypothesis used in this study.

F-SCORE $=1,215-0,261$ ACHANGE -1,514 LEV + 1,443 ROA -1,231 INVENTORY -0,077 BDOUT -0,104

AUDCHNGE + 0,131 DCHNGE + e

\section{DATA ANALYSIS AND DISCUSSION}

\section{Overview of Research Objects}

The population used in this study is the manufacturing financial statements listed on the Indonesia Stock Exchange in the period 2013-2017, which is 155 companies. The author uses the purposive sampling method, after going through the selection stage in determining the sample, there are 30 companies that meet these criteria. Thus, the number of samples that are the object of this study is 150 (30 companies $\times 5$ years). 


\section{Data Analysis}

Descriptive Statistics Analysis

Descriptive statistics are statistics related to the presentation of informative data so that data users are easy to process. Descriptive statistical analysis was carried out to give a description or description of the data in the form of variables, amount of data, maximum value, minimum, average, and standard deviation used in the study (Widarjono 2015).

\section{Results of Descriptive Statistics Analysis}

Descriptive Statistics

\begin{tabular}{lrrrrr}
\hline & N & Minimum & Maximum & Mean & Std. Deviation \\
FSCORE & 150 & $-0,62426$ & 1,43827 & 0,6038440 & 0,39072604 \\
ACHANGE & 150 & $-0,14809$ & 0,80273 & 0,1385162 & 0,16806367 \\
LEVERAGE & 150 & 0,11098 & 0,84085 & 0,4195241 & 0,16804187 \\
ROA & 150 & 0,00084 & 0,26061 & 0,0791510 & 0,05236543 \\
INVENTORY & 150 & $-0,15152$ & 0,14183 & 0,0035562 & 0,04027016 \\
BDOUT & 150 & 0,16667 & 1,00000 & 0,4059524 & 0,11116222 \\
DCHANGE & 150 & 0,0 & 1,0 & 0,380 & 0,4870 \\
AUDCHANGE & 150 & 0,0 & 1,0 & 0,160 & 0,3678 \\
\hline
\end{tabular}

Source : SPSS Output Data

Average Total Independent and Dependent per Year

\begin{tabular}{|c|c|c|c|c|c|}
\hline \multicolumn{6}{|l|}{ FSCORE } \\
\hline Year & 2013 & 2014 & 2015 & 2016 & 2017 \\
\hline Total & 17,07338 & 18,53908 & 17,50123 & 19,37945 & 18,08345 \\
\hline Average & 0,569113 & 0,617969 & 0,583374 & 0,645982 & 0,602782 \\
\hline \multicolumn{6}{|c|}{ ACHANGE } \\
\hline Year & 2013 & 2014 & 2015 & 2016 & 2017 \\
\hline Total & 7,49064 & 3,20524 & 4,03291 & 5,68045 & 4,33614 \\
\hline Average & 0,249688 & 0,106841 & 0,13443 & 0,189348 & 0,144538 \\
\hline \multicolumn{6}{|c|}{ LEVERAGE } \\
\hline Year & 2013 & 2014 & 2015 & 2016 & 2017 \\
\hline Total & 14,22879 & 14,33493 & 14,13254 & 13,48535 & 12,73379 \\
\hline Average & 0,474293 & 0,477831 & 0,471085 & 0,449512 & 0,42446 \\
\hline \multicolumn{6}{|l|}{ ROA } \\
\hline Year & 2013 & 2014 & 2015 & 2016 & 2017 \\
\hline Total & 3,69696 & 3,23304 & 2,40319 & 2,558 & 2,06447 \\
\hline Average & 0,123232 & 0,107768 & 0,080106 & 0,085267 & 0,068816 \\
\hline \multicolumn{6}{|c|}{ INVENTORY } \\
\hline Year & 2013 & 2014 & 2015 & 2016 & 2017 \\
\hline Total & $-0,10605$ & $-0,13308$ & 0,5537 & $-0,08837$ & 0,18435 \\
\hline Average & $-0,00353$ & $-0,00444$ & 0,018457 & $-0,00295$ & 0,006145 \\
\hline \multicolumn{6}{|l|}{ BDOUT } \\
\hline Year & 2013 & 2014 & 2015 & 2016 & 2017 \\
\hline Total & 13,50714 & 13,89048 & 13,85952 & 13,85952 & 13,85952 \\
\hline Average & 0,450238 & 0,463016 & 0,461984 & 0,461984 & 0,461984 \\
\hline DCHANG & & & & & \\
\hline
\end{tabular}




\begin{tabular}{lccccc} 
Year & 2013 & 2014 & 2015 & 2016 & 2017 \\
Total & 11 & 13 & 14 & 14 & 14 \\
Average & 0,366667 & 0,433333 & 0,466667 & 0,466667 & 0,466667 \\
\hline \multicolumn{7}{l}{ AUDCHANGE } & \multicolumn{5}{l}{} \\
\hline Year & 2013 & 2014 & 2015 & 2016 & 2017 \\
Total & 7 & 4 & 5 & 6 & 12 \\
Average & 0,233333 & 0,133333 & 0,166667 & 0,2 & 0,4 \\
\hline
\end{tabular}

Source: Data processed

From the results of the descriptive analysis in the table above, the conclusions that can be taken are as follows: The results of descriptive statistics for the dependent variable, namely fraudulent financial statements as measured by the F-Score showed an average value of 0.6038440 which indicates the average manufacturing company in 2013-2017 had a fraudulent level of financial statements of $60.38 \%$. In table 4.3 changes in percentage of fraud each year undergo fluctuating changes from 2013 2017, the highest rate of fraud in 2016 was 0.645982 or around $64.59 \%$ and the lowest in 2013 was 0.569113 or around $56.91 \%$. In the study of Skousen and Twedt (2009) states that if the resulting average value is low, but the value of the standard deviation is high, the potential for fraud to occur is also higher. The standard deviation of this study is 0.39072604 . This shows that the level of risk of fraud in manufacturing is relatively low.

Based on research conducted by Fauziah (2018) states that the results of the calculation of FScore are grouped to determine the level of risk of fraudulent financial statements in the company. The results of F-Score below one indicates a low or normal risk of fraud, the results above one show results above normal. In table 4.2 it can be seen that the results of descriptive statistical analysis for F-Score show the minimum value of F-Score is -0.62426 owned by Indal Aluminum Industry Tbk in 2015. The maximum value of 1.43827 is owned by Cahaya Kalbar Tbk in 2013. Besides Cahaya Kalbar Tbk, there are three manufacturing companies that have more than one F-Score which has a high risk of fraud. Wismilak Inti Makmur Tbk in 2015 with F-Score of 1.34796, Duta Pertiwi Nusantara Tbk in 2013 with FScore of 1.42737. Then in 2016, there was one company namely Ekadharma International Tbk with FScore of 1.16748. Furthermore, the risk grouping of companies with F-Score above one can be seen in table 4.4.

Fraud Score above One

\begin{tabular}{lllccl}
\hline No. & \multicolumn{1}{c}{ Company name } & Code & Year & $\begin{array}{c}\text { Score } \\
\text { FScore }\end{array}$ & Benchmark F-Score \\
\hline 1. & Wismilak Inti Makmur Tbk & WIIM & 2015 & 1,34796 & Risk above normal \\
2. & Cahaya Kalbar Tbk & CEKA & 2013 & 1,43827 & Risk above normal \\
3. & Duta Pertiwi Nusantara Tbk & DPNS & 2013 & 1,42737 & Risk above normal \\
4. & Ekadharma International & EKAD & 2016 & 1,16748 & Risk above normal \\
& & & & \\
\hline
\end{tabular}

Source: Data processed

In table 4.4 above Wismilak Inti Makmur and Cahaya Kalbar Tbk can be said to be at risk for cheating in financial statements because there is a change in the balance of accounts receivable, in this case, the bills of other parties are quite high at 40.8\% from 2014 to Wismilak Inti Makmur. The highest F-Score number owned by Cahaya Kalbar Tbk has a very large jump in receivables, which is $69.5 \%$ in 2013.

The ratio of changes in total assets in the Duta Pertiwi Nusantara Tbk company for 2013 experienced a fairly high change of $38.8 \%$ and changes in total assets in the company Ekadharma 
International Tbk experienced a high change of $80.2 \%$ which made a potential fraudulent financial report the company is also getting higher.

Based on table 4.2 it can be seen that the results of descriptive statistical analysis for independent pressure variables are proxied into 3 proxies, opportunity independent variables are proxied into 2 proxies, capability variables are proxied into 1 proxy and the rationalization variable is proxied into 1 proxy.

The first pressure variable proxied by financial stability in this study used ACHANGE to measure it. The results of the descriptive statistical analysis for financial stability showed the lowest value of 0.14809 . While the highest value is 0.80273 which means the company has the highest asset change ratio compared to other companies. The average value is 0.1385162 with a standard deviation of 0.16806367 which indicates the level of variation in the data from the variable financial stability. In table 4.3 changes in the percentage of ACHANGE every year experience fluctuating changes from 2013-2017, the highest average rate of change in total assets in 2013 amounted $24.96 \%$ and the lowest in 2014 amounted $10.68 \%$, which can be interpreted as the level of the company's ability to manage assets

The pressure variable seconds proxied by external pressure in the study is calculated by the ratio of leverage. The results of the analysis with descriptive statistics on external pressure showed the lowest value of 0.11098 . While the highest value with an external pressure value of 0.84085 , which means that the company has the highest debt ratio compared to other companies. The average value of 0.4195241 in manufacturing companies with a standard deviation of 0.16804187 shows the level of variation of data from the external pressure variable. In table 4.3 changes in percentage Leverage, every year has fluctuated changes from 2013-2017, the highest average rate of change in debt in 2014 amounted to 47.78\% and the lowest in 2017 amounted $42.44 \%$.

The pressure variable third is proxied by a financial target by calculating Return On Assets (ROA). The results of the descriptive statistical analysis for financial targets show the lowest value of 0,00084, whereas the company with the highest score is 0.26061 , which means that the company has the highest profit ratio compared to other companies. The average of 0.0791510 while the standard deviation of this variable is 0.05236543 which shows the level of variation of data from the financial target variable. In table 4.3 changes in the percentage of ROA every year experience fluctuating changes from 20132017, the highest average rate of changes in earnings in 2013 amounted $12.32 \%$ and the lowest in 2017 amounted $6.88 \%$.

The opportunity variable first proxied by the nature of industry by calculating the ratio of receivables to sales. The lowest descriptive statistical analysis results are -0.15152 while the highest value is a value of 0.14183 . The average of 0.0035562 while the standard deviation of this variable is 0.04027016 which indicates the level of variation in the data from the variable influence of the industrial nature. In table 4.3 changes in the percentage of nature of industry, every year have fluctuated changes from 20132017, the highest average rate of profit changes in 2015 amounted $1.84 \%$ and the lowest in 2014 amounted $0.44 \%$.

The opportunity variables are proxied for the first with effective monitoring by calculating the ratio of the number of independent commissioners to the total commissioners. The results of descriptive statistical analysis of the effective monitoring indicate that the lowest ratio of independent commissioners is 0.16667 and the highest value is 1.00000 . The average of 0.4059524 while the standard deviation of this variable is 0.11116222 which shows the level of variation in the data from the effect of effective monitoring variables. In table 4.3, the annual percentage change in monitoring experiences fluctuating changes from 2013-2017, the highest average rate of change in board of commissioners in 2014 amounted $46.30 \%$ and the lowest in 2016 amounted $46.19 \%$.

Capability variables in this study are proxied by the change of directors measured using the DCHANGE indicator, which examines the change of directors in the company. Based on research on 150 
samples during the 2013-2017 study period produced an average value of 0.380 meaning that $38 \%$ of the sample companies had a change of directors (value 1.00) and the remaining $62 \%$ of companies there was no change of directors (value 0.00 ). The standard deviation value of the board of director changes variable is 0.4870 which shows the level of variation of the data from the variables of the board of directors' influence. In table 4.3 changes in the percentage of changes in the board of directors every year experienced fluctuating changes from 2013-2017, the highest average rate of change in the board of directors in 2016 was 0.466667 or $46.66 \%$ and the lowest in 2013 was equal to 0,366667 or $36.66 \%$.

Rationalization variables are proxied by change in auditor in this study and measured by dummy variables. The results of the study during 2013-2017 with 150 samples produced an average of 0.160 meaning that $16 \%$ of the sample companies made changes to the public accounting firm (score 1 ) while for the remaining $84 \%$ the company did not make changes to the public accounting firm (score 0 ). The standard deviation value of the variable is 0.3678 which indicates the level of variation in the data from the auditor change variable. In table 4.3 changes in the percentage of changes in the board of directors every year experienced fluctuating changes from 2013-2017, the highest average rate of change in the board of directors in 2017 was 0.4 or $40.00 \%$ and the lowest in 2014 was equal to 0,133333 or $13.33 \%$.

This study has passed the classic assumption test, namely the test for normality, multicollinearity, and heteroscedasticity. Furthermore, the test results of the coefficient of determination above, the adjusted $R^{2}$ has a value of 0.596 or $59.6 \%$. It can be concluded that the dependent variable potential fake financial statements can be explained by the independent variables used in this study of $59.6 \%$, the remaining $40.4 \%$ are explained by other variables not used in this study. Based on the ANOVA test or $F$ test, the $F$ value is 29.948 with a significance of 0.000 . Values that are far reaching less than 0.05 , indicate that the Regression model can be used to predict fraudulent financial statements.

\section{Hypothesis Test}

Hypothesis testing is done using the t-test. This test aims to examine the effect of independent variables financial stability, external pressure, financial targets, nature of industry, effective monitoring, rationalization, and capability separately on the dependent variable financial statements fraud (Ghozali, 2013).

Table 4.11 Recapitulation of Hypothesis Test Results

\begin{tabular}{|c|c|c|c|c|}
\hline \multicolumn{2}{|r|}{ Hypothesis } & \multirow{2}{*}{$\frac{B}{-0,261}$} & \multirow{2}{*}{$\frac{\text { Sig. }}{0,051}$} & \multirow{2}{*}{$\frac{\text { Information }}{\text { Rejected }}$} \\
\hline $\mathrm{H} 1$ & $\begin{array}{l}\text { Financial stability has a positive effect on the } \\
\text { potential for financial statements fraud }\end{array}$ & & & \\
\hline $\mathrm{H} 2$ & $\begin{array}{l}\text { External pressure has a positive effect on the } \\
\text { potential for financial statements fraud }\end{array}$ & $-1,514$ & 0,000 & Rejected \\
\hline $\mathrm{H} 3$ & $\begin{array}{l}\text { Financial targets have a positive effect on the } \\
\text { potential for financial statements fraud }\end{array}$ & 1,443 & 0,002 & Accepted \\
\hline $\mathrm{H} 4$ & $\begin{array}{l}\text { Nature of industry has a positive effect on the } \\
\text { potential for financial statements fraud }\end{array}$ & $-1,231$ & 0,021 & Rejected \\
\hline H5 & $\begin{array}{l}\text { Effective monitoring has a negative effect on } \\
\text { the potential for financial statements fraud }\end{array}$ & $-0,077$ & 0,691 & Accepted \\
\hline $\mathrm{H} 6$ & $\begin{array}{l}\text { The capability has a positive effect on the } \\
\text { potential for financial statements fraud }\end{array}$ & $-0,104$ & 0,020 & Rejected \\
\hline $\mathrm{H} 7$ & $\begin{array}{l}\text { Rationalization has a positive effect on the } \\
\text { potential for financial statements fraud }\end{array}$ & 0,131 & 0,025 & Acceptted \\
\hline
\end{tabular}

Source: SPSS output data 
The results of hypothesis testing indicate that the financial stability measured by ACHANGE has a coefficient of -0.261 and a significance level of $0.051>0.05$. This value means that financial stability has a negative and insignificant effect on the potential for fraudulent financial statements. The higher the ratio of changes in assets in a company, the higher the growth value of a company's assets, the lower the potential for fraudulent financial statements that occur. So it can be concluded that hypothesis 1 is rejected.

When a company's financial condition is unstable, the company will not be affected by these conditions. This happened because the company had a good early warning system for its financial stability. These results indicate that the performance of the board of commissioners and internal auditors is very good at overseeing all actions taken by management, especially those related to finance. In addition, the value of asset growth in the company shows the true value of growth, so it is not due to manipulation. So, even though the company's financial condition is unstable, management will not commit fraud. The results of this study support the research conducted by Manurung (2015) and Indarto (2016) concluded that financial targets have a negative and insignificant effect on fraudulent financial statements.In accordance with agency theory used and associated with the results of this study. So, it can be concluded, that the agent must be responsible for all his work against the principal.

When unstable company conditions cause management to be in a depressing situation. Under these conditions, management can maximize the assets it has that cause changes in assets that are stable and in accordance with the expectations of shareholders, these problems will not encourage management to manipulate financial statements to cover financial conditions with unstable conditions.

\section{External pressure effect on the potential of Financial Statements Fraud}

The results of hypothesis testing indicate that external pressure as measured by LEV has a coefficient of -1.622 and a significance level of $0.000<0.05$. This value means that external pressure does not affect the potential for fraudulent financial statements. No matter how large the value of the ratio of total debt to total assets in a company, it does not affect the potential for fraudulent financial statements. So, it can be concluded that hypothesis 2 is rejected.

The results of this study indicate that leverage has no effect on fraudulent financial statements. Management considers that the pressure that comes from debt does not affect them to commit fraud. This happens because companies tend to choose to issue shares to increase their capital rather than making a debt agreement so that it will reduce the pressure to return it someday, and prevent pressure that can lead to fraud (Annisya et al., 2016). But there are also companies that tend to choose to increase funding through debt. This company has confidence if they get additional capital from debt, the business process in the company will be better and improved so that they will get a higher return on their business and can return the debt smoothly, and will prevent potential fraudulent financial statements. The results of this study are consistent with the results of research conducted by Manurung and Hardika (2015), Iqbal and Murtanto (2016), Zaki (2017), and Fuadin (2017).

In accordance with the theory of fraud diamond used and associated with the results of this study. So it can be concluded, that external pressure is a situation where the company gets pressure from parties outside the company. Pressure from external parties will not affect the company's budget to obtain additional debt or sources of funds from external parties in order to remain competitive. To get funds from external parties, the company must display the performance of financial ratios and good profits so that investors are interested. Therefore when a company gets pressure from outside the manager will not manipulate financial statements.

\section{Effect of Financial Targets on the Potential of Financial Statements Fraud}

The results of hypothesis testing indicate that the financial target measured by ROA has a coefficient of 2.502 and a significance level of $0.000<0.05$. This value means that financial targets affect the potential for fraudulent financial statements. Whatever the value of the ratio of net income to total 
assets in a company, affects the potential for fraudulent financial statements. So it can be concluded that hypothesis 3 is accepted.

The results of this study are consistent with the results of research conducted by Sihombing and Rahardjo (2014), Iqbal and Murtanto (2016), Annisya, Lindrianasari, and Asmarani (2016), and Zaki (2017). Increasing the company's financial targets will affect management to commit financial report fraud. This happens because when the company wants to increase its profitability, it will certainly also consider improving the operational quality it has. The company will not hesitate to invest in the form of modernizing information systems in the company, streamlining business processes that are considered wasteful, recruiting experts, and implementing other policies to achieve the set targets. Improvement in the operational quality of the company, management will feel pressure when the company's profitability targets increase.

The results of this study are in accordance with agency theory which states that the agent must be responsible for all his work towards the principal. The company struggles to obtain profits that are in accordance with the target, with the aim of attracting investors' attention to the company. When the resulting profit target is low, it will encourage management to manipulate, so that it is probable that financial statements are presented improperly.

\section{Effect of Nature of Industry on the Potential of Financial Statements Fraud}

The results of hypothesis testing indicate that the nature of industry as measured by INVENTORY has a coefficient of -1.231 and a significance level of $0.021<0.05$. This value means that the nature of industry does not affect the potential for fraudulent financial statements. The higher the ratio value of changes in total inventory in a company, will not affect the potential fraudulent financial statements that occur in the company. So it can be concluded that hypothesis 4 is rejected.

The results of this study support the research conducted by Skousen et al (2008), Manurung (2015), Indarto (2016), and Nugraheni (2017). Management will not commit fraud when total inventory in the company is high. This happens because the more the value of inventory in a company, will not be the potential for theft and fraudulent financial statements. Supervision carried out by the board of commissioners to directly oversee management in making business decisions, guaranteeing the implementation of the company's strategy, and guaranteeing accountability. Supervision by internal auditors is very good at overseeing all actions taken by management.

In accordance with the theory of fraud diamond used and associated with the results of this study. So it can be concluded, that inventory is a current asset that is vulnerable to theft and fraud because inventory in a company is usually in large numbers and has an influence on the balance sheet and profit and loss calculation. Changes in the number of corporate receivables from the previous year cannot be an indication that the company's cash turnover is not good. The accounting process in manufacturing companies is longer, so managers will find it difficult to cheat from the utilization of subjective judgments on obsolete inventory. Therefore, the inventory change ratio does not affect the company management to commit financial statements fraud.

\section{Effect of Effective Monitoring on the Potential of Financial Statements Fraud}

The results of hypothesis testing indicate that effective monitoring as measured by BDOUT has a coefficient of -0.077 and a significance level of $0.691>0.05$. This value means that effective monitoring has a negative and insignificant effect on the potential for fraudulent financial statements. The higher the ratio value of the number of independent commissioners in a company, the higher the potential for fraudulent financial statements that occur, so it can be concluded that hypothesis 5 is accepted.

The results of this study indicate changes in the board of commissioners have no effect on fraudulent financial statements. Companies that have a good supervision system will have an impact on decreasing the potential for the occurrence of earnings management practices carried out by agents or management (Andayani, 2010). The board of commissioners is an accomplice of shareholders to directly oversee management in making business decisions, guaranteeing the implementation of the company's 
strategy, and guaranteeing accountability. In the research of Sihombing and Rahardjo (2014) concluded that the existence of an independent board of commissioners on the board of commissioners would increase the effectiveness of the board in overseeing management performance.

In accordance with the theory of fraud diamond used and associated with the results of this study. So it can be concluded, that the ratio of independent board of commissioners is divided by the total board of commissioners as an effective monitoring indicator. The more the number of independent commissioners in the company, the less the potential for fraudulent financial statements that occur. This happens because the independent board of commissioners is professional in carrying out their duties. The more the number of independent commissioners in the company, the more effective the supervision system. The existence of an independent board of commissioners has a positive contribution to the effectiveness of supervision in the company.

\section{Effects of Change of Directors Substitution on the Potential of Financial Statements Fraud}

The results of hypothesis testing indicate that capability as measured by DCHANGE has a coefficient of -0.104 and a significance level of $0.020<0.05$. This value means that capability does not affect the potential for fraudulent financial statements. As often as any change of directors in a company does not affect the potential for fraudulent financial statements, so it can be concluded that hypothesis 6 is rejected.

The results of this study are in line with the research conducted by Annisya, Lindrianasari, and Asmarani (2016) and Zaki (2017). Substitution of directors in the company does not affect the potential for fraudulent financial statements. This happens because the change of directors is not because the old directors used their ability to commit fraud but because it was caused by something else. In addition, the replacement of new directors can use their position to advance the company and prevent fraud.

In accordance with the theory of fraud diamond used and associated with the results of this study. So it can be concluded, that the submission of authority from the old directors to the new directors with the aim to improve the performance of the previous directors. Change of directors will not affect the company's performance and can be said to be successful when the new directors can prevent and reduce fraudulent financial statements. The results of the board of directors' change did not affect the fraudulent financial statement, this can be said because the supervision of the board of commissioners was related to the performance of each board of directors. In addition, the change of directors made it possible to change management perform better than before, because of the recruitment of more competent directors.

\section{Effects of Change Auditor on the Potential of Financial Statements Fraud}

The results of hypothesis testing indicate that auditor changes as measured by AUDCHANGE have a coefficient of 0.131 and a significance level of $0.025<0.05$. This value means that rationalization has an effect on the potential for fraudulent financial statements. Substitution of external auditors in a company affects the potential for fraudulent financial statements, so it can be concluded that hypothesis 7 is accepted.

The results of this study support the research conducted by Skousen et al (2008), and Iqbal (2016). Substitution of external auditors in the company affects the potential for fraudulent financial statements. This happens because company management is accustomed to external auditors who have good performance so that when there is a change of auditor or not, they will still commit fraud and rationalization of cheating becomes a habit. This habit eventually became the company's organizational culture. What must be done by the company in executing work contracts with external auditors who have a good track record. In addition, companies must be able to create and familiarize attitudes not to rationalize cheating on every individual in the company and make it an organizational culture (Siddiq and Hadinata, 2016).

The results of this study are in accordance with the theory of fraud diamond which states that auditor changes are attitudes that allow a person to commit fraud and consider his actions to be natural. 
Actors involved in fraudulent financial statements consistently rationalize the fraud by modifying rules or codes of ethics. This is because new external auditors still do not understand the overall condition of the company, so there is fraud committed by management that is not detected by the external auditor.

\section{CONCLUSIONS}

This study aims to determine the effect of financial stability, external pressure, financial targets, nature of industry, effective monitoring, rationalization, and capability on the potential variable of fraudulent financial statements in manufacturing companies listed on the Indonesia Stock Exchange during the 2013-2017 period. Based on research, conclusions can be taken as follows: (1) The financial stability (ACHANGE) variable proved not to have a positive and insignificant effect on the potential fraudulent financial statements. This happened because the company had a good early warning system on the condition of financial stability. (2) External pressure variable (LEV) proved to have no positive and significant effect on the potential for fraudulent financial statements. (3) The financial target (ROA) proved to have a positive and significant effect on the potential for fraudulent financial statements. (4) The nature of industry variable (INVENTORY) proved to have no positive and significant effect on the potential for fraudulent financial statements. (5) Variable effective monitoring (BDOUT) proved to have a negative and no significant effect on the potential for fraudulent financial statements. (6) Variable capability (DCHANGE) proved to have no positive and significant effect on the potential for fraudulent financial statements. (7) Variable rationalization (AUDCHANGE) proved to have a positive and significant effect on potential fraudulent financial statements.

The implications of the results of this study are mainly on financial target financial variables and auditor change variables which are proven to have a significant positive effect on fraudulent financial statements. The results of this study are expected to provide benefits to users of financial statements, especially in manufacturing companies, one of which is to consider management as the responsible and agent in protecting shareholders. In addition, investors can be used as a tool that provides information to be more careful in considering investments. For creditors as consideration when giving credit or loans to companies. The users of financial statements can use the financial target variable to detect whether the company has the potential for fraudulent financial statements, so that it can be used for appropriate decision making. $\quad$ Further research is expected to add to the financial reporting period under study so that more samples are obtained, and the results can reflect the actual conditions. Future research is expected to add more variables used to detect financial statements, add variable explanatory proxies, and use other new indicators that are deemed feasible to use, for example using pentagon fraud analysis in detecting fraudulent financial statements. Financial report users can use the ratio of total inventory change as a detection of fraudulent financial statements, because in this study the ratio proved to be used as an indicator of fraudulent financial statements.

\section{REFERENCE}

ACFE. (2016). Report to Nations. Association of Certified Fraud Examiners. Austin. Retrieved from https://www.acfe.com/rttn2016/docs/2016-report-to-the-nations.pdf

(2018). Report to Nations. Association of Certified Fraud Examiners. Austin. Retrieved from www.acfe.com/uploadedFiles/ACFE_Website/ Content/rttn/2018/RTTN- Asia-PacificEdition.pdf

Aghghaleh S.F, et al. (2016). Detecting Financial Statement Frauds In Malaysia: Comparing The Abilities Of Beneish and Dechow Models. Asian Journal of Accounting anf Governance, Vol 7(2016). http://dx.doi.org/10.17576/AJAG-2016-07-05

Ahsan, Habib. (2013). Overvalued equities and audit fees: a research note. Vol. 28 Issue: 8, pp.755-776, https://doi.org/10.1108/MAJ-01-2013-0818. 
AICPA. (2002). AU Section 316 Consideration of Fraud in a Financial, (99, 113), 167-218.

Albrecht et al. (2012). Fraud Examination (4th ed.). South-Western: Cengage Learning.

Annisya, et al. (2016). Pendeteksian Kecurang Laporan Keuangan Menggunakan Fraud Diamond. Jurnal Bisnis Dan Ekonomi (JBE), 23(1), 72-89.

Andayani, T.D. (2010). Pengaruh Karakteristik Dewan Komisaris dan Komite Audit terhadap Manajemen Laba (Studi Pada Perusahaan Manufajtur yang Terdaftar di Bursa Efek Indonesia). Tesis, Universitas Diponegoro.

Cressey, D. R. (1953). Other People's Money: A Study in the Social Psychology of Embezzlemente. New Jersey: Patterson Smith.

Dechow, P. M., Ge, W., Larson, C. R., and Sloan, R. G. (2011). Predicting Material Accounting Misstatements. Contemporary Accounting Research, Vol. 28 No. 1, 17-82. Available athttps://doi.org/10.1111/j.1911-3846.2010.01041.x

Effendi, M. A. (2008). The Power Of Good Corporate Governance: Teori dan Implementasi. Jakarta: Salemba Empat.

Ernst \& Young. (2009). Deterrence and detection of financial fraud. Available at www.ey.com/Publication/vwLUAssets/Deterrence_and_detection_of_financial_fraud/\$FILE/EY -Deterrence-and-detection-of-financial-fraud.pdf on September 24, 2018.

Ghozali, I. (2013). Aplikasi Analisis Multivariate Dengan Program SPSS (7th ed.). Semarang: BP Universitas Diponegoro.

Indarto, S. L., and Ghozali, I. (2016). Fraud Diamond: Detection Analysis on The Fraudulent Financial Reporting. Risk Governance \& Control: Financial Markets \& Institutions, 6(4), 116-123.

Integrity-indonesia.com.( 2017, September 14). Skandal Keuangan Perusahaan Toshiba. Accessed from https://integrity-indonesia.com/id/blog/2017/09/14/skandal-keuangan-perusahaan-toshiba/

Iqbal, M., and Murtanto. (2016). Analisa Pengaruh Faktor-Faktor Fraud Triangle terhadap Kecurangan Laporan Keuangan pada Perusahaan Proferty dan Real Estate yang Terdaftar di Bursa Efek Indonesia. Seminar Nasional Cendikiawan 2016, (2002), 17.2-17.20.

Jensen, M. C., dan Meckling, W. H. (1976). Theory of the Firm: Managerial Behavior, Agency Costs and Ownership Structure. Journal of Financial Economics, 3(4), 305-306

Kurniawansyah, D. (2018). Apakah Manajemen Laba Termasuk Kecurangan? : Analisis Literatur. Vol. 3, No 1, pp.341-356, http://dx.doi.org/10.31093/jraba.v3i1.97

Loebbecke, J. K., Eining, M. M., and Willingham, J. J. (1989). Auditors' Experience with Material Irregularities: Frequency, Nature, and Detectability. Auditing: A Journal of Practice \& Theory, 9(1), 1-28.

Manurung, D. T. H., and Hardika, A. L. (2015). Analysis of factors that influence financial statement fraud in the perspective fraud diamond: Empirical study on banking companies listed on the Indonesia Stock Exchange year 2012 to 2014. Paper dipresentasikan di International Conference on Accounting Studies 2015, Johor, Johor Baru, Malaysia, 17-20 Agustus.

Nanda Santoso. (2017). Predicting Financial Statement Fraud with Fraud Diamond Model of Manufacturing Companies Listed in Indonesia. pp 151-163, 10.1007/978-981-10-6926-0_9 
Nugraheni, N. K and Triatmoko, H. (2017). Analisis Faktor-faktor yang mempengaruhi terjadinya Financial Statement Fraud : Perpektif Fraud diamond Theory (Studi Pada Perusahaan Perbankan Yang Terdaftar Di Bursa Efek Indonesia Periode 2014-2016). Journal Akuntansi dan Auditing. Vol 14, No 2. https://doi.org/10.14710/jaa.14.2.118-143

Nurbaiti, Z., \& Hanafi, R. (2017). Analisis Pengaruh Fraud Diamond Dalam Mendeteksi Tingkat Accounting Irregularities. Jurnal Akuntansi Indonesia, Vol. 6 No. 2, 167-184.

Paul M. Healy and James M. Wahlen (1999) A Review of the Earnings Management Literature and Its Implications for Standard Setting. Accounting Horizons: December 1999, Vol. 13, No. 4, pp. 365383.

Prasmaulida, S. (2016). Financial Statement Fraud Detection Using Perspective of Fraud Triangle Adopted by SAS No. 99. Asia Pacific Fraud Journal, 1(2), 317. https://doi.org/10.21532/apfj.001.16.01.02.24

Richardson, S. A., Sloan, R. G., Soliman, M. T., dan Tuna, I. (2005). Accrual reliability, earnings persistence and stock prices. Journal of Accounting and Economics, 39(3), 437-485. https://doi.org/10.1016/j.jacceco.2005.04.005

Skousen, C. J., Smith, K. R., and Wright, C. J. (2008). Detecting and predicting financial statement fraud: the effectiveness of the fraud traingle and. Retrieved from http://ssrn.com/abstract=1295494

(2009). Fraud in Emerging Markets: A Cross Country Analysis. Retrieved from http://ssrn.com/abstract=1340586

Siddiq, F. R., \& Hadinata, S. (2016). Fraud Diamond Dalam Financial Statement Fraud. Jurnal Bisnis Dan Manajemen Islam, Vol.4, No. 2

Sihombing, K. S., and Rahardjo, S. N. (2014). Analisis Fraud Diamond Dalam Mendeteksi Financial Statement Fraud: Studi Empiris Pada Perusahaan Manufaktur Yang Terdaftar Di Bursa Efek Indonesia ( Bei ) Tahun 2010-2012. Diponegoro Journal of Accounting, 3(2).

. (2014). Analisis Fraud Diamond Dalam Mendeteksi Financial Statement Fraud: Studi Empiris Pada Perusahaan Manufaktur Yang Terdaftar Di Bursa Efek Indonesia ( Bei ) Tahun 2010-2012. Diponegoro Journal of Accounting, 3(2).

Sukrisnadi, D. (2010). Pemakaian Ukuran F-Score dalam Kasus-Kasus Salah Saji Laporan Keuangan di Pasar Modal Indonesia. Tesis, Universitas Indonesia

(2010). Pemakaian Ukuran F-Score dalam Kasus-Kasus Salah Saji Laporan Keuangan di Pasar Modal Indonesia. Tesis, Universitas Indonesia.

Summers, S. L., dan Sweeney, J. T. (1998). Fraudulently Mistated Financial Statements An and Insider Trading An Empirical Analysis. The Accounting Review, 73(1), 131-146

Sunardi, S. and Amin, N, M. (2018). Fraud detection of financial statement by using fraud diamond perspective. International Journal of Development and Sustainability. Vol. 7 No. 3, pp. 878-891.

Suyono, Eko. (2017). Berbagai Model Pengukuran Earning Management: Mana yang paling akurat. Prosiding Seminar Nasional \& Call for Paper (SCA 2017) FEB UNSOED. Vol 7, No 1. 303-324.

Wahyuninngtias, Fauziah. 2016. Analisis Elemen-Elemen Fraud Diamond Sebagai Determinan Finansial Statement Fraud Pada Perusahaan Perbankan Di Indonesia. The Master of Accounting Study Thesis Program was published, Universitas Airlangga. 
Wells, J. (2011). Principles of Fraud Examination (Third Edit). New Jersey: John Wiley and Sons.

Widarjono, A. (2015). Statistika Terapan dengan Excell dan SPSS (1st ed.). Yogyakarta: UPP STIM YKPN.

Widarti. (2015). Pengaruh Fraud Trriangle Terhadap Deteksi Kecurangan Laporan Keuangan Pada Perusahaan Manufaktur yang Terdaftar di Bursa Efek Indonesia (BEI). 230-244

Wolfe, D. T., and Hermanson, D. R. (2004). The Fraud Diamond: Considering the Four Elements of Fraud. CPA Journal, 12(74), 38-42.

Wahyuninngtias, Fauziah. 2016. Analisis Elemen-Elemen Fraud Diamond Sebagai Determinan Finansial Statement Fraud Pada Perusahaan Perbankan Di Indonesia. The Master of Accounting Study Thesis Program was published, Universitas Airlangga. 